\title{
Effect of lesions of A5 or A7 noradrenergic cell group or surgical transection of brainstem catecholamine pathways on plasma catecholamine levels in rats injected subcutaneously by formalin
}

\author{
Boris Mravec $^{1,2}$, Ibolya Bodnar ${ }^{3}$, Gabriela Uhereczky ${ }^{3}$, Richard Kvetnansky ${ }^{1}$ and Miklos \\ Palkovits ${ }^{3}$ \\ ${ }^{1}$ Institute of Experimental Endocrinology, Slovak Academy of Sciences, Bratislava, Slovak Republic \\ ${ }^{2}$ Institute of Pathophysiology, Faculty of Medicine, Comenius University, Bratislava, Slovak Republic \\ ${ }^{3}$ Neuromorphological and Neuroendocrine Research Laboratory, Hungarian Academy of Sciences and Semmelweis Univer- \\ sity, Budapest, Hungary
}

\begin{abstract}
The pain-induced activation of the sympatho-adrenal system is modulated by several brain areas, including brainstem catecholamine cell groups. In the present study, we evaluated the effect of bilateral lesions of the A5 or A7 cell groups or bilateral transections of brainstem catecholaminergic pathways on plasma catecholamine levels in Sprague-Dawley rats injected subcutaneously by formalin or saline. Plasma levels of both epinephrine and norepinephrine were slightly elevated after formalin injections within 15-30 min in rats with or without lesions of the A7 catecholamine cell group. However, saline but not formalin elicited a significant increase in plasma epinephrine level in both sham-operated and A5-lesioned groups. It is more likely, that formalin blocks the effect of the handling and the painful injection procedure. In rats with bilateral partial transections of the lower brainstem, formalin was more effective than saline in the elevation of plasma epinephrine and norepinephrine levels at several time-points through the investigation period. Our data indicate the involvement of A5 and A7 norepinephrine neurons and brainstem catecholaminergic pathways in the regulation of the activity of the sympatho-adrenal system during acute painful situations. Their modulatory effect, however, seems to be a very rapid one, short and moderate.
\end{abstract}

Key words: Pain — Epinephrine - Norepinephrine - Catecholamine bundles — Sympatho-adrenal System

\section{Introduction}

Ascending brainstem catecholaminergic pathways, involving both ventral and dorsal noradrenergic bundles, may participate in the transmission of nociceptive signals to several forebrain areas that elaborate consequent behavioral and neuroendocrine responses to painful stimuli (Palkovits 2002). Moreover, axons originating in A5-A7 noradrenergic cell groups participate also on descending modulation of transmission of pain at the level of spinal

Correspondence to: Boris Mravec, Institute of Experimental Endocrinology, Slovak Academy of Sciences, Vlarska 3, 83306 Bratislava, Slovak Republic

E-mail: ueenmrav@savba.sk cord (Stamford 1995; Millan 1997, 2002; Nuseir and Proudfit 2000).

Subcutaneous administration of formalin represents one of the most frequently used experimental models of pain in laboratory animals (Dubuisson and Dennis 1977; Porro and Cavazzuti 1993; Walker et al. 1999; Pacak and Palkovits 2001). In conscious rats, subcutaneous formalin injection into the hind paw provokes a brief initial and a prolonged second phase characterized by behavioral responses, including intense licking, flicking and even biting of the injected paw (Abbott et al. 1995). Moreover, administration of formalin evokes strong activity in the sympatho-neural system and hypothalamic-pituitary-adrenocortical axis. The activity of the adrenomedullary hormonal system depends on the concentration and volume of applied formalin solutions 
(Culman et al. 1997; Pacak et al. 1998; Mravec et al. 2004, 2005).

In the present study we examined the effect of bilateral lesions of A5 or A7 noradrenergic cell groups, and the effect of bilateral transection of brainstem catecholaminergic pathways on the acute response to painful stimuli on the activity of the sympatho-adrenal system characterized by norepinephrine (NE) and epinephrine (EPI) levels in the plasma.

\section{Materials and Methods}

\section{Animals}

The experiments were carried out using male Sprague-Dawley rats weighing $330 \pm 30 \mathrm{~g}$ (Charles Rivers, Gödöllö, Hungary). One week before starting experiments, animals were kept under controlled conditions in the animal room (12 h light $/ 12 \mathrm{~h}$ dark cycle, lights at 06:00 h; temperature, $22 \pm 1^{\circ} \mathrm{C}$ ) with free access to tap water and standard pelleted rat chow. Experiments were performed between 08:00-12:00 h. All external noises or any other stressful stimuli were avoided.

Experiments were approved by the Ethics Committee of the Institute of Experimental Endocrinology, Bratislava, Slovakia and by the Ethic Committee of Semmelweis University, Budapest, Hungary (based on the European Communities Council Directive of 24 November 1986 (86/609/EEC) regarding the care and use of animals for experimental procedures).

\section{Lesion of catecholamine cell groups and transection of catecholamine pathways}

Rats were exposed to bilateral electrocoagulation of either the A5 or A7 cell groups, or bilateral mechanical transection of the brainstem catecholamine pathways. Interventions were performed 2 weeks before the experiments to provide adequate duration of time for regeneration of animals after brain surgery.

\section{Lesions of A5 or A7 cell groups}

Bilateral electrocoagulation of A5 or A7 cell groups were performed by platinum coated electrodes using a constant current device (Lesion Making Device, Ugo Basile). Parameters for guide of electrode tip according to stereotaxic atlas (Paxinos and Watson 1997):

- A5 cell group: antero-posterior $=-10.1 \mathrm{~mm}$; vertical $=$ $-9.9 \mathrm{~mm}$, horizontal $= \pm 2.3 \mathrm{~mm}$;

- A7 cell group: antero-posterior $=-8.0 \mathrm{~mm}$; vertical $=-8.6$ $\mathrm{mm}$, horizontal $= \pm 1.7 \mathrm{~mm}$.

Current intensity: $35 \mathrm{~mA}$, duration of current flow: $25 \mathrm{~s}$. Success of lesion was evaluated after the experiment by slicing of brains (for details, see Kvetnansky et al. 2006).
Transection of brainstem catecholaminergic pathways

Parameters for guide of "glass knife" prepared from standard microscopic cover glass (Palkovits et al. 1982) according to stereotaxical atlas (Paxinos and Watson 1997): anteroposterior $=-8.2 \mathrm{~mm}$; vertical $=-11.0 \mathrm{~mm}$, horizontal $=$ $\pm 1.8 \mathrm{~mm}$. The width of knife was $1.5 \mathrm{~mm}$. The declination of knife was approximately $9^{\circ}$ (for details see Kvetnansky et al. 2006). Brainstem catecholaminergic pathways were transected bilaterally. The success of transections was evaluated on histological sections at the end of the experiment.

\section{Sham-operations}

The animals were treated as the operated ones (anesthesia, fixation of the head in the stereotaxic device, open the skull and the dura) but no electrodes or knives were introduced into the brain. The post-surgical procedure and treatments were the same as for operated rats.

\section{Cannulation of the tail artery}

One day prior to blood sampling, the rats were anaesthetized with a mixture containing $60 \mathrm{mg} / \mathrm{kg}$ ketamine and $7.8 \mathrm{mg} / \mathrm{kg}$ xylazine. A permanent cannula (silicon tubing, inner diameter $0.5 \mathrm{~mm}$, external diameter 0.9 mm, Becton-Dickinson, Parsippany, NJ, USA) was implanted into the tail artery (Chiueh and Kopin 1978). The free end of the cannula was drawn under the skin to the back of the neck and exited to the top of the cage through a flexible stainless steel spring fixed to the skin by adhesive tape. The tube was flushed with heparinized saline $(300 \mathrm{IU} / \mathrm{ml})$. This procedure allows frequent blood sampling from freely moving rats without any influence of unwanted stressors. After cannulations, rats were housed individually.

At each collection, $0.5 \mathrm{ml}$ of blood was obtained and the same volume of heparinized saline $(50 \mathrm{IU} / \mathrm{ml})$ was injected back, as a replacement for the lost volume.

\section{Experimental design}

The animals have been divided into 8 groups:

- sham-operated rats with saline or formalin injections,

- A5-lesioned rats with saline or formalin injections,

- A7-lesioned rats with saline or formalin injections,

- pathways-transected rats with saline or formalin injections.

Immediately after the baseline blood collection through the chronically implanted tail artery, animals were handled and either $0.2 \mathrm{ml} / 100 \mathrm{~g}$ b.w. of $4 \%$ formalin solution or equal volume of saline were injected subcutaneously into hind 
limbs. Then, blood samples were collected 5, 15, 30, 60 and 120 min after injections.

\section{Analysis of blood samples}

Blood plasma was separated by centrifugation and stored at $-70^{\circ} \mathrm{C}$ until assayed for catecholamines. Plasma levels of EPI and NE were measured by radioenzymatic assay (Peuler and Johnson 1977). Shortly, catecholamines present in plasma aliquots were converted into their labeled O-methylated derivatives by using $\mathrm{S}$ - $[3 \mathrm{H}]$-adenosylmethionine (Amersham, Little Chalfont, UK) and a lyophilized catechol-O-methyltransferase isolated from rat liver. Then, the O-methylated derivatives of the amines were extracted along with unlabeled carrier compounds, separated by thin-layer chromatography, eluted and reacted with periodate. The detection limit was 5 pg EPI or NE per tube.

\section{Statistical analysis}

Statistical analysis of the data was performed by repeated measures ANOVA, using the different treatments as between-subject factor and the different time points when blood sampling occurred as within subject factor. All data are expressed as means \pm SEM. $p<0.05$ was taken as indicative of statistical significance for the tests.

\section{Results}

Effect of catecholaminergic cell groups lesion or transection of catecholaminergic pathways on baseline plasma catecholamine levels

Bilateral electrocoagulation of A5 or A7 noradrenergic cell groups or transection of brainstem catecholaminergic pathways did not affect significantly baseline plasma EPI and NE levels (Tab. 1).

Saline and formalin injections into the sham-operated animals

A slight but insignificant increase in plasma EPI levels was recorded in sham-operated rats $5 \mathrm{~min}$ after injections of saline. This level was gradually depleted to the initial concentration by $120 \mathrm{~min}$. Formalin injection elicited an increase in plasma EPI levels by the $30^{\text {th }} \mathrm{min}$. Then, the values in different time points of the investigated period remained elevated or gradually decreased by the end of the investigation period (Fig. 1A).

Plasma NE concentrations were elevated by $5^{\text {th }}$ and $30^{\text {th }}$ min after saline injections, and then the values returned to the initial levels. The formalin-induced elevations in NE levels were also slight, but somewhat higher than those recorded after saline injections, and they stayed in that level till 120 min (Fig. 1B).

\section{Saline and formalin injections to A5-lesioned animals}

Saline elicited very high plasma EPI concentrations in the first $5 \mathrm{~min}$, much higher than in sham-operated rats. This high level was decreased gradually by time, but it remained still higher than that in sham-operated rats up to $60 \mathrm{~min}$ after injection (Fig. 1A). Formalin elicited any alterations in plasma EPI levels during the investigated period, although the values were somewhat higher than those elicited by saline (Fig. 1A).

A5-lesioned rats established moderate elevations in plasma NE levels in the first 5 min after saline injections, as high as after formalin injections (Fig. 1B). Both values were higher than those in the formalin- or saline-injected

Table 1. Effect of catecholaminergic cell groups lesion or transection of brainstem catecholaminergic pathways on baseline plasma catecholamine levels

\begin{tabular}{llcc}
\hline Type of intervention & Group & $\begin{array}{c}\text { Plasma epinephrine levels } \\
(\mathrm{pg} / \mathrm{ml})\end{array}$ & $\begin{array}{c}\text { Plasma norepinephrine levels } \\
(\mathrm{pg} / \mathrm{ml})\end{array}$ \\
\hline \multirow{3}{*}{ A5 lesion } & Sham-saline & $37 \pm 8$ & $262 \pm 49$ \\
& Sham-formalin & $36 \pm 10$ & $313 \pm 27$ \\
& A5 lesion-saline & $42 \pm 9$ & $289 \pm 36$ \\
& A5 lesion-formalin & $35 \pm 5$ & $296 \pm 30$ \\
\cline { 2 - 3 } A7 lesion & Sham-formalin & $67 \pm 20$ & $309 \pm 41$ \\
& A5 lesion-formalin & $91 \pm 18$ & $421 \pm 62$ \\
\cline { 2 - 3 } Transection of catecholaminergic & Sham-saline & $48 \pm 19$ & $443 \pm 60$ \\
pathways & Sham-formalin & $46 \pm 16$ & $456 \pm 46$ \\
& Transection-saline & $26 \pm 10$ & $412 \pm 62$ \\
\hline
\end{tabular}

Each value is the mean \pm SEM. 
A

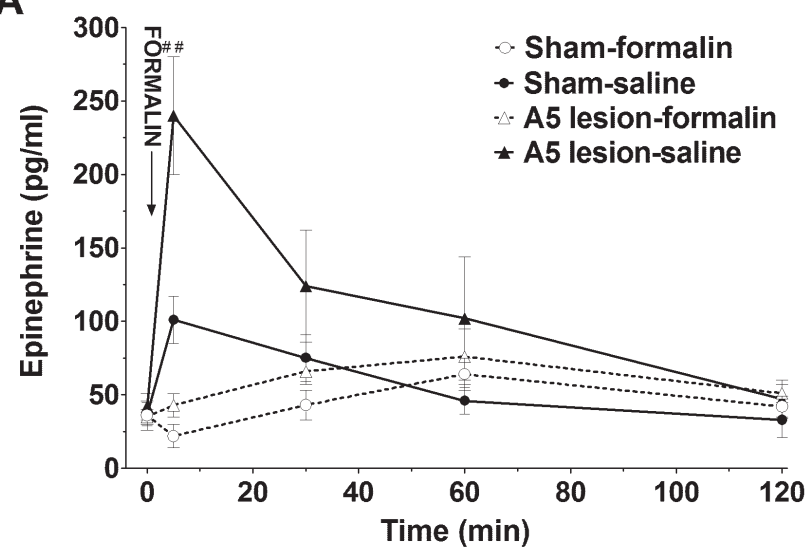

B

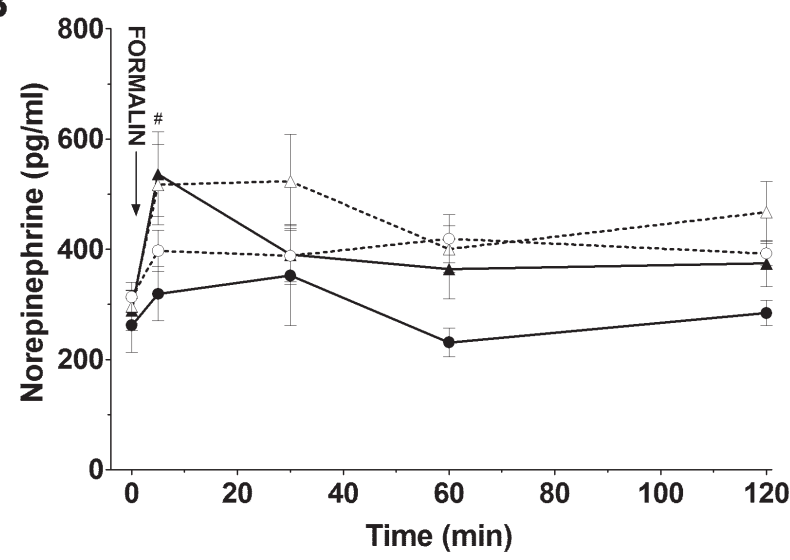

Figure 1. Effect of handling combined with subcutaneous injection of saline $(\boldsymbol{\Lambda} ; n=8)$ or formalin $(\Delta ; n=8)$ to rats with $\mathrm{A} 5$ cell group lesions or sham-operated rats injected by saline $(\bullet ; n=9)$ or formalin $(\circ ; n=8)$ on plasma epinephrine (A) and norepinephrine (B) levels. Each value is the mean \pm SEM. ${ }^{\#} p<0.05,{ }^{\# \#} p<0.01$ vs. saline group.

sham-operated group. In further time points, plasma NE concentrations in formalin-injected rats remained high till $30 \mathrm{~min}$, while the saline-injected group returned to the initial level by that time (Fig. 1B).

\section{Saline and formalin injections to A7-lesioned animals}

Bilateral lesions of the A7 group did not alter plasma EPI levels in response to either formalin or saline injections (Fig. 2A).

Formalin injection produced an immediate increase in plasma NE levels in sham-operated animals. This concentration, about twice as high as the initial value remained unaltered tills the end of the sampling (Fig. 2B). Although the NE concentrations were somewhat higher, it should be noted that the formalin-induced elevation of plasma NE levels were almost the same as after saline injections (Fig. 2B).
Saline and formalin injections to animals with transected brainstem catecholaminergic pathways

Injection of saline produced a rise in the plasma EPI concentration $5 \mathrm{~min}$ after application. Then, this level declined between 15 and $60 \mathrm{~min}$, and further declined by $120 \mathrm{~min}$, down to the initial concentration (Fig. 3A). In contrast, formalin elicited high plasma EPI levels by $60 \mathrm{~min}$ which were depleted by the end of blood sampling. In comparison, formalin was more effective on plasma EPI concentration in transected rats than saline (Fig. 3A).

Both injections of formalin and saline elicited a moderate rapid increase in plasma NE level at the first $15 \mathrm{~min}$, then the levels are dissociated: they were stable in the saline-treated rats, but they further elevated in the formalin-injected group (Fig. 3B).
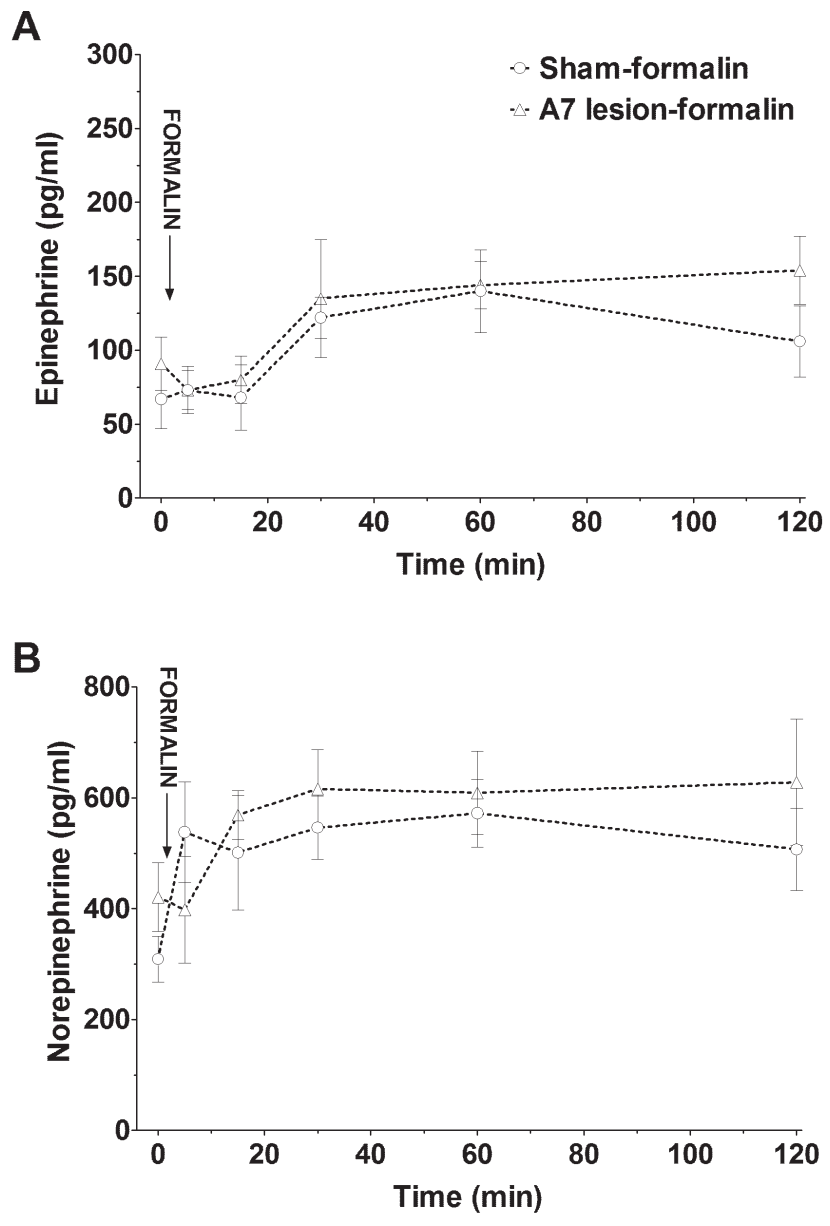

Figure 2. Effect of handling combined with subcutaneous injection of formalin to rats with A7 area lesions $(\Delta ; n=7)$ or sham-operated rats $(\circ ; n=9)$ on plasma epinephrine (A) and norepinephrine (B) levels. Each value is the mean \pm SEM. 
A
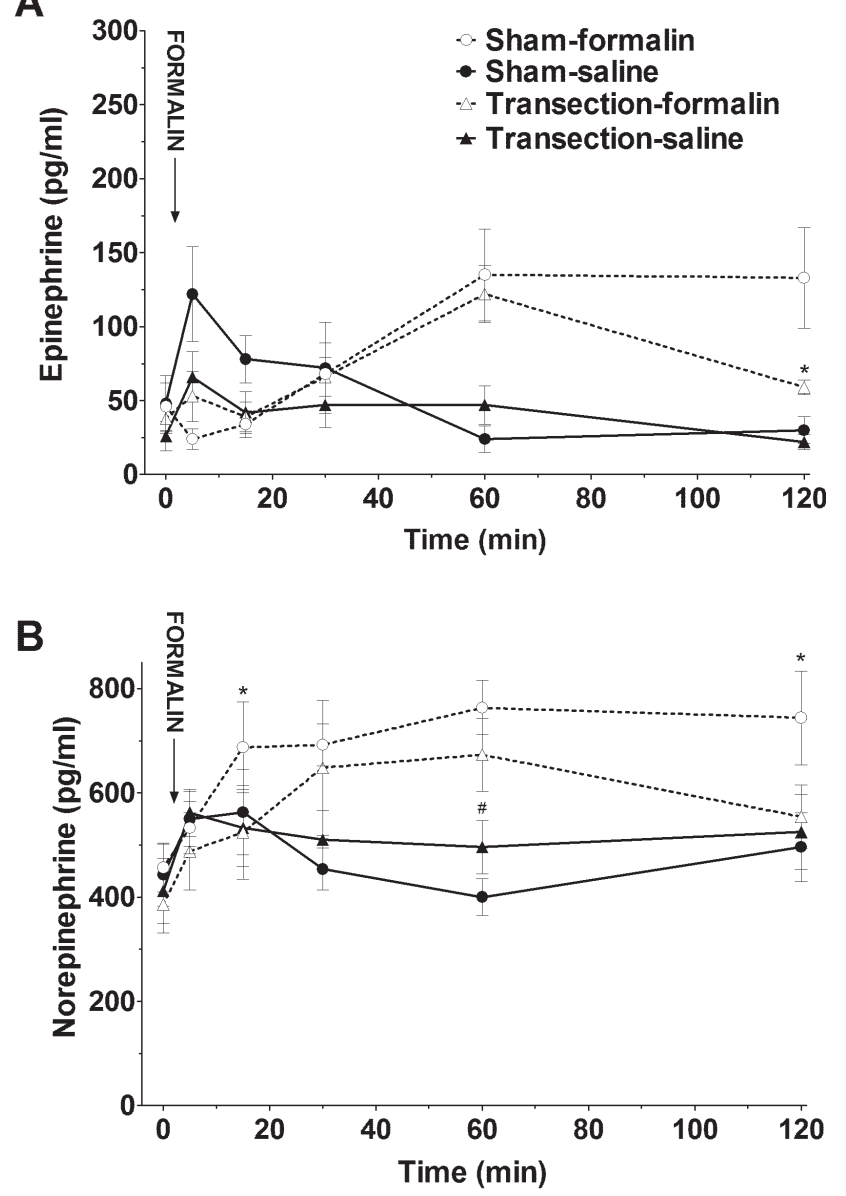

Figure 3. Effect of handling combined with subcutaneous injection of saline $(\boldsymbol{\Delta} ; n=8)$ or formalin $(\Delta ; n=8)$ to rats with transected catecholaminergic pathways or sham-operated rats injected by saline $(\bullet ; n=9)$ or formalin $(\circ ; n=9)$ on plasma epinephrine (A) and norepinephrine (B) levels. Each value is the mean \pm SEM. ${ }^{*} p<$ $0.05 v$ s. formalin group; ${ }^{\#} p<0.05 v$ s. saline group.

Application of saline or formalin in all above mentioned experiments was performed in handled animals. Therefore saline- or formalin-induced changes in plasma catecholamine levels represents combination of effects of handling and injection of saline or formalin.

\section{Discussion}

Nociceptive signals from the spinal cord and the brainstem reach neurons in the lower brainstem catecholaminergic cell groups (Menetrey and Basbaum 1987; Lima et al. 1991; Tavares et al. 1996; Palkovits et al. 1997; Palkovits 2002). Here, we investigated the effect of lesioning of selected catecholamine neurons or pathways in the lower brain stem on the activity of the sympatho-adrenal system in response to acute painful stimuli.

Both ascending and descending axons arise in brainstem catecholamine neurons. The ascending ventral and dorsal noradrenergic bundles originating mainly in neurons located in the A1/A2 and C1/C2 cell groups reach in various parts of the forebrain and participate in behavioral and neuroendocrine response to the painful stimuli (Palkovits 2002). In addition to ascending catecholamine pathways, descending pathways also arise in the lower brainstem and participate in pain inhibition (Millan 1997; Willis and Westlund 1997; Barnes and Sharp 1999; Millan 2002). The spinal cord is directly innervated by $\mathrm{A} 1 / \mathrm{C} 1, \mathrm{~A} 5, \mathrm{~A} 6$ and $\mathrm{A} 7$ catecholamine groups of the brainstem (Kwiat and Basbaum 1992; Tavares et al. 1996; Westlund and Craig 1996). Combinations of immunohistochemical and track tracer techniques have shown that axons of A5-A7 cell groups of the pons densely innervate dorsal horns of spinal cord. This arrangement of catecholaminergic synapses constitutes basis for modulation of processing of nociceptive signals at spinal cord level (Byrum et al. 1984; Hagihira et al. 1990; Clark and Proudfit 1991; 1993). Experimental data suggest that signals produced by formalin-induced chemical and/or inflammatory nociception are under the modulation of the monoaminergic (noradrenergic and serotonergic) descending inhibitory systems (Omote et al. 1998). Experiments using electrical or chemical stimulation methods confirmed involvement of A5 and $\mathrm{A} 7$ region in modulation of nociceptive processes in the spinal cord (Stamford 1995; Nuseir and Proudfit 2000; Bajic and Commons 2010; Marques-Lopes et al. 2010). A5 and A7 neurons act as sympathetic premotor neurons by innervating the intermediolatral cell column in the thoracic spinal cord and activate the sympatho-adrenal system for responding to painful stimuli. Therefore we investigated the effect of bilateral electrolytic lesion of A5 or A7 cell groups on sympatho-adrenal system responses (acute epinephrine and norepinephrine release) in rats injected by formalin or saline.

The formalin test represents one of the traditional animal models of pain in small laboratory animals (Dubuisson and Dennis 1977; Culman et al. 1997; Henry et al. 1999). Formalin pain elicits activation of brainstem areas involving catecholaminergic groups (Palkovits et al. 1995; Palkovits et al. 1997). Subcutaneous applications of formalin elicit pain behavioral responses (Abbott et al. 1995), increase the blood pressure and heart rate (Culman et al. 1997), and elevate the levels of NE, ACTH, corticosterone and prolactin in the plasma (Kant et al. 1982; Pacak et al. 1998; Vissers et al. 2004). However, epinephrine secretion depends on the concentration and the volume of applied formalin solution (Culman et al. 1997; Pacak et al. 1998; Mravec et al. 2004; Mravec et al. 2005).

Handling, a necessary component of manipulation with animals during injection of formalin, significantly 
elevates EPI and NE plasma levels (Kvetnansky et al. 1978; Dobrakovova and Jurcovicova 1984; Castagne et al. 1987; Kvetnansky et al. 1992). However, in our experiments we observed attenuated EPI release in first 15 min after formalin administration in handled animals. These observations are consistent with our previous reports showing that subcutaneous injection of $0.2 \mathrm{ml} / 100 \mathrm{~g}$ b.w. of $4 \%$ formalin attenuates stress-induced elevations of EPI in the plasma during first 15-30 minutes after application (Mravec et al. 2004, 2005).

Formalin acts on EPI and NE levels in both sham-operated and transected rats. Only differences that formalinelicited high plasma EPI and NE levels diminished by 180 min, while it was constantly high in transected animals. This observation indicates that formalin may act on sympathetic cells in the spinal cord. The transection of the ascending ventral and dorsal catecholaminergic bundles may influence the activity of certain forebrain neurons (O'Donohue et al. 1979) but not the supraspinal pain-inhibitory system.

A7 lesions did not block formalin-induced elevation on either EPI or NE levels in the plasma, the sympatho-adrenal system immediately activated, like in sham-lesioned rats. The effect of lesions seems to be a long-acting one, constantly high values at the end of the experiment (180 min), while somewhat declined in sham-operated animals. This finding clearly suggests that A7 noradrenergic neurons have minor effect on pain-related peripheral catecholamines release from the adrenal or sympathetic nerve terminals.

The A5 cell groups represent the major sympathetic premotor cell population that innervate the sympathetic preganglionic neurons, their bilateral lesions do not prevent a short-term response (acute NE release) to either saline or formalin injections (Fig. 1). It may tell us that: 1) the majority of A5 neurons are lesioned, and 2) formalin-pain may be less effective in this response than handling and the injection procedure itself. It clearly shows in EPI responses: saline elicited very strong but short lasting effect in lesioned rats, while formalin did not elicit NE release either in shamoperated or A5 lesioned rats. It is necessary to take in consideration that electrolytic lesion of A5 cell groups affects both noradrenergic neurons and pathways running through lesioned brain region.

One point, however, should be underlined. Either A5 or A7 lesions, even bilateral transactions of ascending catecholaminergic pathways at pontine level failed alone to make long-lasting dramatic changes in plasma EPI or NE levels. This observation supports the former hypothesis, that the brainstem catecholaminergic neurons constitute a system (or ascending and descending systems), lesioning of any parts of this system, the other (surviving) neurons are able to compensate the lost of the lesions one. This compensation may be not as complete as the response of intact rats but they are able to keep the "system" working. This ability of the system should be, in certain cases, important to keep the animals alive in tough stressful conditions.

Acknowledgements. This work was supported by the Slovak Research and Development Agency under the contract No. APVV0148-06, No. APVV-0007-10 and VEGA grant No. 2/0010/09.

\section{References}

Abbott F. V., Franklin K. B., Westbrook R. F. (1995): The formalin test: scoring properties of the first and second phases of the pain response in rats. Pain 60, 91-102 http://dx.doi.org/10.1016/0304-3959(94)00095-V

Bajic D., Commons K. G. (2010): Visualizing acute pain-morphine interaction in descending monoamine nuclei with Fos. Brain Res. 1306, 29-38 http://dx.doi.org/10.1016/j.brainres.2009.10.010

Barnes N. M., Sharp T. (1999): A review of central 5-HT receptors and their function. Neuropharmacology 38, 1083-1152 http://dx.doi.org/10.1016/S0028-3908(99)00010-6

Byrum C. E., Stornetta R., Guyenet P. G. (1984): Electrophysiological properties of spinally-projecting A5 noradrenergic neurons. Brain. Res. 303, 15-29 http://dx.doi.org/10.1016/0006-8993(84)90206-3

Castagne V., Corder R., Gaillard R., Mormede P. (1987): Stressinduced changes of circulating neuropeptide $\mathrm{Y}$ in the rat: comparison with catecholamines. Regul. Pept. 19, 55-63 http://dx.doi.org/10.1016/0167-0115(87)90074-7

Clark F. M., Proudfit H. K. (1991): The projection of noradrenergic neurons in the A7 catecholamine cell group to the spinal cord in the rat demonstrated by anterograde tracing combined with immunocytochemistry. Brain Res. 547, 279-288 http://dx.doi.org/10.1016/0006-8993(91)90972-X

Clark F. M., Proudfit H. K. (1993): The projections of noradrenergic neurons in the A5 catecholamine cell group to the spinal cord in the rat: anatomical evidence that $\mathrm{A} 5$ neurons modulate nociception. Brain Res. 616, 200-210 http://dx.doi.org/10.1016/0006-8993(93)90210-E

Culman J., Ritter S., Ohlendorf C., Haass M., Maser-Gluth C., Spitznagel H., Unger T. (1997): A new formalin test allowing simultaneous evaluation of cardiovascular and nociceptive responses. Can. J. Physiol. Pharmacol. 75, 1203-1211 http://dx.doi.org/10.1139/y97-141

Dobrakovova M., Jurcovicova J. (1984): Corticosterone and prolactin responses to repeated handling and transfer of male rats. Exp. Clin. Endocrinol. 83, 21-27 http://dx.doi.org/10.1055/s-0029-1210308

Dubuisson D., Dennis S. G. (1977): The formalin test: a quantitative study of the analgesic effects of morphine, meperidine, and brain stem stimulation in rats and cats. Pain 4, 161-174 http://dx.doi.org/10.1016/0304-3959(77)90130-0

Hagihira S., Senba E., Yoshida S., Tohyama M., Yoshiya I. (1990): Fine structure of noradrenergic terminals and their synapses in the rat spinal dorsal horn: an immunohistochemical study. Brain Res. 526, 73-80 http://dx.doi.org/10.1016/0006-8993(90)90251-6 
Henry J. L., Yashpal K., Pitcher G. M., Coderre T. J. (1999): Physiological evidence that the 'interphase' in the formalin test is due to active inhibition. Pain 82, 57-63 http://dx.doi.org/10.1016/S0304-3959(99)00033-0

Chiueh C. C., Kopin I. J. (1978): Hyperresponsivitiy of spontaneously hypertensive rat to indirect measurement of blood pressure. Am. J. Physiol. 234, H690-695

Kant G. J., Meyerhoff J. L., Bunnell B. N., Lenox R. H. (1982): Cyclic AMP and cyclic GMP response to stress in brain and pituitary: stress elevates pituitary cyclic AMP. Pharmacol. Biochem. Behav. 17, 1067-1072 http://dx.doi.org/10.1016/0091-3057(82)90495-6

Kvetnansky R., Bodnar I., Shahar T., Uhereczky G., Krizanova O., Mravec B. (2006): Effect of lesion of a5 and a7 brainstem noradrenergic areas or transection of brainstem pathways on sympathoadrenal activity in rats during immobilization stress. Neurochem. Res. 31, 267-275 http://dx.doi.org/10.1007/s11064-005-9016-4

Kvetnansky R., Goldstein D. S., Weise V. K., Holmes C., Szemeredi K., Bagdy G., Kopin I. J. (1992): Effects of handling or immobilization on plasma levels of 3,4-dihydroxyphenylalanine, catecholamines, and metabolites in rats. J. Neurochem. 58, 2296-2302 http://dx.doi.org/10.1111/j.1471-4159.1992.tb10977.x

Kvetnansky R., Sun C. L., Lake C. R., Thoa N., Torda T., Kopin I. J. (1978): Effect of handling and forced immobilization on rat plasma levels of epinephrine, norepinephrine, and dopaminebeta-hydroxylase. Endocrinology 103, 1868-1874 http://dx.doi.org/10.1210/endo-103-5-1868

Kwiat G. C., Basbaum A. I. (1992): The origin of brainstem noradrenergic and serotonergic projections to the spinal cord dorsal horn in the rat. Somatosens. Mot. Res. 9, 157-173 http://dx.doi.org/10.3109/08990229209144768

Lima D., Mendes-Ribeiro J. A., Coimbra A. (1991): The spino-latero-reticular system of the rat: projections from the superficial dorsal horn and structural characterization of marginal neurons involved. Neuroscience 45, 137-152 http://dx.doi.org/10.1016/0306-4522(91)90110-A

Marques-Lopes J., Pinho D., Albino-Teixeira A., Tavares I. (2010): The hyperalgesic effects induced by the injection of angiotensin II into the caudal ventrolateral medulla are mediated by the pontine A5 noradrenergic cell group. Brain Res. 1325, 41-52 http://dx.doi.org/10.1016/j.brainres.2010.02.043

Menetrey D., Basbaum A. I. (1987): Spinal and trigeminal projections to the nucleus of the solitary tract: a possible substrate for somatovisceral and viscerovisceral reflex activation. J. Comp. Neurol. 255, 439-450 http://dx.doi.org/10.1002/cne.902550310

Millan M. J. (1997): The role of descending noradrenergic and serotoninergic pathways in the modulation of nociception: focus on receptor multiplicity. In: Handbook of Experimental Pharmacology. The Pharmacology of Pain. (Eds. A. H. Dickenson, K. L. Melmon, J. M. Besson), pp. 385-446, Springer-Verlag, Heidelberg

Millan M. J. (2002): Descending control of pain. Prog. Neurobiol. 66, 355-474

http://dx.doi.org/10.1016/S0301-0082(02)00009-6

Mravec B., Bodnar I., Kubovcakova L., Nagy G. M., Palkovits M., Kvetnansky R. (2004): Inhibitory effect of formalin administra- tion on immobilization-induced epinephrine release. Ann. N. Y. Acad. Sci. 1018, 105-112 http://dx.doi.org/10.1196/annals.1296.012

Mravec B., Bodnar I., Uhereczky G., Nagy G. M., Kvetnansky R., Palkovits M. (2005): Formalin attenuates the stress-induced increase in plasma epinephrine levels. J. Neuroendocrinol. $17,727-732$ http://dx.doi.org/10.1111/j.1365-2826.2005.01365.x

Nuseir K., Proudfit H. K. (2000): Bidirectional modulation of nociception by GABA neurons in the dorsolateral pontine tegmentum that tonically inhibit spinally projecting noradrenergic A7 neurons. Neuroscience 96, 773-783

http://dx.doi.org/10.1016/S0306-4522(99)00603-X

O’Donohue T. L., Crowley W. R., Jacobowitz D. M. (1979): Biochemical mapping of the noradrenergic ventral bundle projection sites: evidence for a noradrenergic--dopaminergic interaction. Brain Res. 172, 87-100 http://dx.doi.org/10.1016/0006-8993(79)90897-7

Omote K., Kawamata T., Kawamata M., Namiki A. (1998): Formalin-induced nociception activates a monoaminergic descending inhibitory system. Brain Res. 814, 194-198 http://dx.doi.org/10.1016/S0006-8993(98)01086-5

Pacak K., Palkovits M. (2001): Stressor specificity of central neuroendocrine responses: implications for stress-related disorders. Endocr. Rev. 22, 502-548 http://dx.doi.org/10.1210/er.22.4.502

Pacak K., Palkovits M., Yadid G., Kvetnansky R., Kopin I. J., Goldstein D. S. (1998): Heterogeneous neurochemical responses to different stressors: a test of Selye's doctrine of nonspecificity. Am. J. Physiol. 275, R1247-1255

Palkovits M. (1999): Stress-related central neuronal regulatory circuits. In: Stress: Neural, Endocrine and Molecular Studies. (Eds. R. McCarty, G. Aguilera, E. L. Sabban, R. Kvetnansky), pp 1-9, Taylor and Francis, London

Palkovits M., Baffi J. S., Dvori S. (1995): Neuronal organization of stress response. Pain-induced c-fos expression in brain stem catecholaminergic cell groups. Ann. N. Y. Acad. Sci. 771, 313-326 http://dx.doi.org/10.1111/j.1749-6632.1995.tb44691.x

Palkovits M., Baffi J. S., Pacak K. (1997): Stress-induced Fos-like immunoreactivity in the pons and the medulla oblongata of rats. Stress 1, 155-168 http://dx.doi.org/10.3109/10253899709001105

Palkovits M., Tapia-Arancibia L., Kordon C., Epelbaum J. (1982): Somatostatin connections between the hypothalamus and the limbic system of the rat brain. Brain Res. 250, 223-228 http://dx.doi.org/10.1016/0006-8993(82)90416-4

Paxinos G., Watson C. (1997): The Rat Brain in Stereotaxic Coordinates. Academic Press, New York

Peuler J. D., Johnson G. A. (1977): Simultaneous single isotope radioenzymatic assay of plasma norepinephrine, epinephrine and dopamine. Life Sci. 21, 625-636 http://dx.doi.org/10.1016/0024-3205(77)90070-4

Porro C. A., Cavazzuti M. (1993): Spatial and temporal aspects of spinal cord and brainstem activation in the formalin pain model. Prog. Neurobiol. 41, 565-607 http://dx.doi.org/10.1016/0301-0082(93)90044-S

Stamford J. A. (1995): Descending control of pain. Br. J. Anaesth. $75,217-227$ 
Tavares I., Lima D., Coimbra A. (1996): The ventrolateral medulla of the rat is connected with the spinal cord dorsal horn by an indirect descending pathway relayed in the A5 noradrenergic cell group. J. Comp. Neurol. 374, 84-95 http://dx.doi.org/10.1002/(SICI)1096-9861(19961007)374:1<84:: AID-CNE6>3.0.CO;2-J

Vissers K. C., De Jongh R. F., Crul B. J., Vinken P., Meert T. F. (2004): Adrenalectomy affects pain behavior of rats after formalin injection. Life Sci. 74, 1243-1251 http://dx.doi.org/10.1016/j.lfs.2003.07.040

Walker K., Fox A. J., Urban L. A. (1999): Animal models for pain research. Mol. Med. Today 5, 319-321
http://dx.doi.org/10.1016/S1357-4310(99)01493-8

Westlund K. N., Craig A. D. (1996): Association of spinal lamina I projections with brainstem catecholamine neurons in the monkey. Exp. Brain Res. 110, 151-162 http://dx.doi.org/10.1007/BF00228547

Willis W. D., Westlund K. N. (1997): Neuroanatomy of the pain system and of the pathways that modulate pain. J. Clin. Neurophysiol. 14, 2-31

http://dx.doi.org/10.1097/00004691-1997010

Received: January 4, 2012

Final version accepted: February 16, 2012 